\title{
Žensko iskustvo migracija i starenja - pogled s otokâ
}

DOI: $10.11567 /$ met.30.3.5

UDK: 314.7:612.67]-055.2(497.5)(210.7)

612.67:314.7]-055.2(497.5)(210.7)

Prethodno priopćenje

Primljeno: 30.9.2014.

Prihvaćeno: 14.11.2014.

\section{Sonja Podgorelec}

Institut za migracije i narodnosti, Zagreb

sonja.podgorelec@imin.hr

\section{Mario Bara}

Hrvatsko katoličko sveučilište, Zagreb

mario.bara@unicath.hr

\section{SAŽETAK}

Rad je rezultat istraživanja osobitosti migracija i njihova utjecaja na starenje žena u specifičnom prostoru otoka, uzrokâ i društvenih posljedica tih procesa te razmatranja nekih domena kvalitete života važnih starim ljudima. Uz pregled teorijskih radova autori svojevrsnim isprepletanjem podataka prikupljenih metodama analize sekundarnih podataka, promatranja i polustrukturiranog intervjua nastoje objasniti starenje u prostoru hrvatskih otoka s pozicija uloge roda. Kvalitativni podaci prikupljeni su tijekom više istraživanja u okviru projekta »Utjecaj migracija na regionalni razvoj Hrvatske« od 2003. do 2013. U fokusu analize pretežno su iskustva starijih žena koje žive u malim otočnim zajednicama, definiranim na temelju sličnosti gospodarskih, društvenih i psiholoških parametara neovisno o veličini otoka. Podaci predstavljeni u radu upućuju na to da starenje žena na otocima i kvaliteta života u starosti ovise o brojnim čimbenicima - (ne)sudjelovanju u migracijama njih samih ili članova njihovih obitelji, veličini zajednice u kojoj žive, stupnju izoliranosti otoka, kvaliteti postojeće infrastrukture, njihovu zdravlju, stupnju uključenosti u društveni život itd. Ono što je zajedničko starim ženama bez obzira na specifičnost pojedinačnoga životnog ciklusa ili otok na kojem žive visoka je razina aktivnosti do duboke starosti. Zaključak je rada da se u narednom razdoblju, na osnovi postojećih demografskih trendova, očekuje nastavak procesa starenja stanovništva hrvatskih otoka, porast broja staračkih samačkih kućanstava u kojima u znatno većem broju žive žene, nastavak ravnopravnosti u podjeli uloga između otočana i otočanki u domeni rada izvan kuće, a zadržavanje »ženskih uloga « unutar doma i u skrbi za starije (profesionalno ili volonterski), što će produbiti neke probleme vezane uz kvalitetu života stanovnika malih otočnih zajednica.

KLJUČNE RIJEČI: žene, migracije, starenje, otoci, otočna zajednica 


\title{
Selo na otoku
}

\author{
U zanosu kada gledan \\ ta kamena zdanja \\ tu svi ljudi ka i kuće \\ ranog su izdanja.
}

Toni Cukrov, 2009.

\section{UVOD}

Uz uobičajene atribute kojima se opisuju hrvatski otoci - njihovu brojnost, prirodne karakteristike (razvedenost i kvaliteta obalnog prostora, vrijednost okoliša, gospodarska osnova i klima) te razinu očuvanosti arhitekture i tradicijske kulture (jezika i običaja), kada se pozornost usmjeri na stanovništvo, tri su značajke uvijek u prvom planu: malobrojnost stanovnika, veliki udio starih ljudi te posebice veliki udio žena među starijima. Prema podacima popisa stanovništva 2011., na hrvatskim otocima živjelo je 124.955 stanovnika, od toga 62.114 muškaraca i 62.841 žena. Odnos broja žena i muškaraca mijenja se s dobi, pa broj žena raste među stanovništvom starim 60 i više godina. Značajni porast udjela žena bilježi se nakon sedamdesete godine (gdje ih je za trećinu više nego muškaraca), a posebice u skupini starijih starih ljudi ${ }^{1}$ (Popis stanovništva, kućanstava $i$ stanova 2011). Udio starih i žena među starima posebno je izražen na manjim ${ }^{2}$ otocima, na kojima u pravilu žive male populacije.

Život otočnih zajednica hrvatskog dijela Jadrana umnogome je sličan zbog istih geografskih osobitosti prostora u kojem žive (odvojenost otoka od kopna, sličnost tla i klime), povijesnih događaja kojima su bile izložene kao i gospodarskih uvjeta koji su odredili/određuju način njihova života danas, a koje je najjednostavnije obuhvatiti pojmom otočnosti. Ipak, koliko god bile slične, otočne zajednice razlikuju se po nekim specifičnim elementima onoliko koliko se razlikuju pojedinačni životni ciklusi njihovih članova i u mjeri u kojoj je jedinstvenost pojedinca ugrađena u život zajednice.

1 Podjela na skupine - stari ljudi (od dobne skupine 60 - 65 godina do 75 ili 80 godina) i stariji stari ljudi (stariji od 80 godina) načinjena je ponajprije prema utvrđenoj znatnoj razlici u tjelesnom zdravlju, određivanju prioriteta zadovoljavanja potreba, stupnju aktivnosti i načinu svakodnevnoga života (Suzman i Riley, 1985, u: Schaie i Willis, 2001: 78-80).

2 O raznim definicijama malog otoka u hrvatskim razmjerima više u: Podgorelec i Klempić Bogadi (2013: 13-14). 
Značajnost uloge svakog člana raste s obzirom na vrstu zajednice u kojoj živi (ruralna ili urbana), njezinu veličinu i stupanj aktivnosti pojedinca. S obzirom na temu rada iskustvo starenja žena na otocima valja promatrati i u kontekstu njihova »položaj[a] (...) koji najbolje dolazi do izražaja u različitim kontekstima odnosa s ostalim društvenim sudionicima (obaju spolova) u određenim trenucima [njihova] životnog ciklusa« (Riquer, 1990: 60, u: Minđek, 1997: 50-51).

U istraživanjima starenja manje je teorijske pozornosti usmjereno na starije žene, koje često zauzimaju niže pozicije u društvu u odnosu na muškarce svih dobi, i mlađe žene, napose u smislu analize njihova ekonomskog statusa. Posljedica je to dominantnih teorija u području sociologije poput funkcionalističkih i političko-ekonomskih teorija starenja, koje se može »optužiti« da su bile »slijepe u pogledu roda «(Powell, 2006: 55). Posljednjih desetljeća znanstvenici su značajno pridonijeli istraživanju uloge žena tijekom starenja. Primjeri uključuju »uvid u muške i ženske uloge u pružanju skrbi, uključujući i njihove odnose s obitelji i prijateljima u društvenim mrežama podrške (Antonucci, 1990; Antonucci i Akiyama, 1987), rodna iskustva rada i umirovljenja (Ginn i sur., 2001; Harrington Meyer, 1996) te spolno uvjetovanu podjelu kućanskih poslova (Calasanti i Slevin, 2001)« (Street, 2007: 160).

Starenje se može promatrati i kao feminističko pitanje zbog niza uloga koje žene obavljaju u privatnoj (skrb za obitelj) i javnoj sferi (društvene i ekonomske aktivnosti) (Hooyman, 2002: 488). Takva je situacija i u otočnim populacijama, uz naglasak na malim hrvatskim otocima, na kojima udio žena u starijim dobnim skupinama značajno raste. Muškarci i žene starenje doživljavaju drugačije (Arber i Ginn, 1995). Ističe se da većina razlika u iskustvu starenja između starijih žena i muškaraca temeljno nije biološka, već nastaje zbog strukture društva i rodno definiranih uloga (Arber, Davidson i Ginn, 2003: 4). Naime društvene uloge i zaposlenja gotovo su u pravilu rodno usmjereni. Status žena i muškaraca pri napuštanju tržišta rada oblikovan je rodnim procesima, rodnim iskustvom rada i definiranjem produktivnih i reproduktivnih aktivnosti prihvatljivih muškarcima i ženama. Žene su bez obzira na dob nerijetko za iste poslove manje plaćene od svojih muških kolega. Posljedično primaju i niže mirovine, pa će se nakon umirovljenja starije žene susresti s većim brojem ekonomskih nejednakosti i poteškoća nego stariji muškarci (Arber, Davidson i Ginn, 2003).

Analiza široko definiranog iskustva starenja u prostoru otoka nužno sadržava i određivanje domena, odnosno dimenzija kvalitete života njihovih stanovnika. Budući da je kvaliteta života višedimenzionalni koncept koje- 
mu znanstvenici prilaze s različitih pozicija, za potrebe ovoga rada koristit ćemo se širim pristupom koji uzima u obzir podjednako analizu životnih uvjeta: okoliš i kulturu, koji kvalitetu života otočnog stanovništva određuje na specifični način, kao i pojedinačno iskustvo pojedinca, tj. njegovu procjenu određenih područja života poput zdravlja, osjećaja bliskosti (unutar obitelji i u lokalnoj zajednici), solidarnosti, doživljaja sigurnosti i osamljenosti. Dakle konceptu kvalitete života pristupamo uzimajući u obzir objektivne uvjete i subjektivnu vrijednost određenih dimenzija života (George i Bearon, 1980; Hughes, 1993; Cummins, 1997).

Upravo zbog brojnosti starijih žena u otočnim zajednicama danas te specifičnog položaja i uloga koje su imale (preuzimale) u određenim (ranijim) razdobljima života pojedine lokalne zajednice, a u ovisnosti o ključnim događajima koji su određivali pojedinačne životne cikluse, ${ }^{3}$ izdvajanje ženskog iskustva starenja u prostoru otoka tema je koja zaslužuje znanstvenu pozornost.

\section{METODOLOŠKE NAPOMENE}

Tema su ovoga rada migracije i njihov utjecaj na starenje žena u specifičnom prostoru otoka, uzroci i društvene posljedice tih procesa te razmatranje nekih domena kvalitete života posebice važnih starim ljudima. Prvi dio rada bavi se pregledom migracija na otocima, njihovim uzrocima te razlikama u spolnoj zastupljenosti među migrantima u povijesnim i suvremenim okvirima, kao i posljedicama migracija na radne i društvene uloge članova otočnih zajednica. Slijedi dio u kojem se analiziraju normativna očekivanja u vezi s rodnim ulogama, položajem i ponašanjem starijih osoba u društvu pod utjecajem gospodarskih, strukturnih i kulturnih čimbenika, a vezano uz nalaze nekih domena kvalitete života starijih žena u lokalnim otočnim zajednicama (rad i aktivnosti, zdravlje, slobodno vrijeme i međugeneracijska solidarnost).

\footnotetext{
»Perspektiva životnog ciklusa posebice je važna za razumijevanje uvjeta u kojima žive stari ljudi jer su uzorci dobivene i očekivane potpore u starosti dio kontinuirane interakcije roditelja, djece i drugih rođaka tijekom njihova života, odnosno 'putovanja' kroz povijesno vrijeme. (...) Perspektiva životnoga ciklusa pomaže objasniti u kojoj su mjeri problemi, potrebe i načini prilagodbe starih ljudi oblikovani njihovim ranijim životnim doživljajima, iskustvima i povijesnim uvjetima (Hareven, 2001: 142). Promatramo li starenje žena na hrvatskim otocima te događaje koji su odredili njihovo iskustvo starenja, možemo zaključiti da je riječ o kontinuirano snažnom iseljavanju tijekom dvadesetog stoljeća, iskustvu dvaju svjetskih ratova, nemogućnosti školovanja na otocima, gospodarskim uvjetima u zemlji, ratnim razaranjima priobalja u posljednjem ratu, ekonomskom kolapsu dalmatinskoga gospodarstva devedesetih godina 20. stoljeća, rastu stope nezaposlenosti posljednjih desetak godina i dr.
} 
Potrebno je naglasiti da će se, premda je u naslovu rada implicirana analiza (pregled) dosadašnjih spoznaja o ženskom iskustvu starenja na hrvatskim otocima, rad oslanjati pretežno na iskustva starijih žena koje žive u malim otočnim zajednicama. Male otočne zajednice karakterizira sličnost gospodarskih, socioloških i psiholoških parametara bez obzira na veličinu otoka na kojem se nalaze, ali i iznimna osjetljivost na bilo koju promjenu koja se unutar zajednice odvija. Jedan od glavnih fenomena koji se na hrvatskim otocima kontinuirano odvija tijekom posljednjih stotinjak godina jest migracija, koja je mijenjala smjerove ovisno o povijesnim trenucima $\mathrm{u}$ kojima se nalazio prostor Hrvatske, a koji su određivali prije svega gospodarski, a potom i cjelokupni društveni razvoj otočnog prostora, pa tako i položaj i ulogu otočanki.

Posljedice migracija na život stanovništva, ponajprije na promjenu demografskih struktura, a posljedično i na društvene i radne uloge članova otočnih zajednica, nužno je pratiti kroz duže razdoblje. $S$ obzirom na mali broj radova koji se ciljano bave nekim od aspekata starenja žena u prostoru otoka (u Hrvatskoj i izvan nje) za potrebe ovoga rada odlučili smo, uz uobičajeno navođenje teorijskih radova koji se bave migracijama i starenjem (prije svega socioloških, demografskih i etnoloških) te sekundarnih podataka (popisâ stanovništva), analizu temeljiti i na podacima prikupljenim tijekom više provedenih istraživanja u kojima smo sudjelovali. ${ }^{4}$ Naime od 2003. do 2013. u sklopu projekta »Utjecaj migracija na regionalni razvoj Hrvatske« Instituta za migracije i narodnosti provedena su istraživanja na Silbi, Krku, Cresu, Lošinju i Drveniku (Podgorelec, 2008), Prviću, Zlarinu, Kaprijama, Žirju i Krapnju (Podgorelec i Klempić Bogadi, 2013) te na Zlarinu, Kaprijama, Žirju i Lošinju (Bara, 2013). Ciljevi istraživanja nisu se potpuno preklapali, ali u svima je uz promatranje i anketu upotrijebljena kvalitativna metoda istraživanja polustrukturirani intervju, odnosno biografski pristup ${ }^{5} \mathrm{u}$ prikupljanju podataka o načinu i kvaliteti života otočana kao i o ulozi migracija u raznim razdobljima njihova života - bilo kao dio njihova životnog ciklusa ili onoga njihovih roditelja (najčešće očeva). Uzorke istraživanja činili su stanovnici svih dobnih skupina (zadarski i šibenski otoci te Lošinj) ili samo stariji otočani (Krk, Cres, Silba i Drvenik). Temu žene i starenje u prostoru hrvatskih otoka uz podatke prikupljene istraživanjima nastojali smo potkrijepiti i odabranim citatima o otočnim temama

4 Riječ je o odabiru intervjua (ukupno 28 koji su odgovarali temi ovog rada) na koje smo se referirali.

5 Biografsko istraživanje »rabi priče pojedinaca i drugi 'osobni materijal' za razumijevanje individualnog života u društvenom kontekstu« (Roberts, 2002: 4). 
iz domaće književnosti (pjesništva posvećenog otočnim temama) te nekim poslovicama uvriježenim u promatranim otočnim zajednicama. Dakle za potrebe rada upotrijebili smo neke objavljene podatke, odnosno izjave sugovornikâ (odgovore na pitanja, odnosno dijelove njihovih životnih priča), ali i neobjavljene izjave i podatke prikupljene terenskim radom. Uza svako navođenje citata pojedinog sugovornika bit će navedeni spol, dob, otok, godina te vrijeme i mjesto provedenog intervjua. Način na koji smo pristupili analizi prikupljenih kvalitativnih podataka i zaključcima najbliži je metodi retrodukcije, odnosno »stiliziranom opisu koji temeljimo na općim pravilima i izoliranim slučajevima " Fuglsang i Olsen, 2003: 28, u: Holst i Plange Welleius, 2006/2007: 16). Retrodukcija je nerijetko polazišna metoda feminističkih teorija utemeljenih na terenskim istraživanjima, kojom se logični zaključci temelje na analizi poznatih činjenica odabranih prema promatranom problemu. Dakle riječ je o svojevrsnom isprepletanju podataka prikupljenih metodama analize sekundarnih podataka, promatranja i polustrukturiranih intervjua, odnosno primjenom dedukcije i indukcije, koji nam omogućuju objašnjenje starenja u prostoru hrvatskih otoka s pozicije uloge roda, odnosno u ovom slučaju pozicije otočanki.

Svjesni smo da takav pristup podacima prikupljenima u više istraživanja provedenih u nepravilnim vremenskim razmacima, ali na slično oblikovanom uzorku, ima prednosti i ograničenja. Stoga ćemo prilikom donošenja određenih zaključaka (a onda i njihova poopćivanja na ukupnu otočnu populaciju) rad tretirati kao izviđajno istraživanje, odnosno izvedene zaključke valja shvatiti kao polazišnu točku za neko buduće sveobuhvatno ciljano istraživanje o položaju i ulozi žena u razvoju otočnih zajednica, odnosno starenju žena u specifičnom prostoru otoka te posljedicama starenja na kvalitetu njihova života.

\section{OTOČANKE I MIGRACIJA - POVIJESNI OKVIR}

Demografska, socijalna i razvojna perspektiva hrvatskih otoka u znatnoj su mjeri određene položajem ovisnosti i rubnosti u odnosu na kopno. Razlike u njihovoj veličini i naseljenosti, položaju i prometnoj povezanosti značajne su za kvalitetu i organizaciju načina života stanovništva. Migracije, promatrane u posljednjih stotinjak godina, bile su i jesu važni čimbenik oblikovanja načina života pripadnika otočnih zajednica, a često i nužnost opstanka. Premda su se razlozi seljenja mijenjali tijekom vremena, glavnina je potaknuta gospodarskim razvojem države, odnosno stupnjem razvoja ili zaostajanja otočnoga prostora u odnosu na kopneni. 
Velikim promjenama u migracijskim strujanjima, kao posljedicama niza ekonomskih, društvenih i političkih zbivanja krajem 19. i tijekom 20. stoljeća, otoci postaju dominantno emigracijska područja, što će uvelike utjecati na njihov demografski i društveno-gospodarski razvoj (Graovac, 2004; Faričić, Graovac i Čuka, 2010; Podgorelec i Klempić Bogadi, 2013).

Demografska posljedica seljenja uglavnom mlađeg stanovništva s otokâ tijekom 20. stoljeća, a u posljednjih dvadesetak godina povratak iseljenih otočana u umirovljeničkoj dobi, jest depopulacija koju je slijedilo ukupno starenje stanovništva (Nejašmić, 2013). Posebice je brojno starije stanovništvo na malim hrvatskim otocima, na kojima je 2011. prosječna starost iznosila 55,4 godine (Lajić i Mišetić, 2013). Iseljavanje djeluje kao samogenerirajući čimbenik jer ostaje na snazi i nakon prestanka inicijalnih razloga za iseljavanje, a prije svega se odražava u narušenoj dobno-spolnoj strukturi i nemogućnosti samoreprodukcije zajednice.

Nekadašnju brojnost stanovništva malih otočnih naselja, ${ }^{6}$ a današnju demografsku pustoš jedna od sugovornica istraživanja sažela je u izjavu: »Kad sam se ja rodila [1930. u Ustrinama, otok Cres], bilo je jedno 220 ljudi i poslije sve na manje, na manje svake godine. Sad ih ima možda 20« (Ž, 78, Cres, 2007). Izumiranje malih naselja u unutrašnjosti otoka slikovito opisuje i sugovornik na Cresu: „Četiri smo muška u Lubenicama. Ima ženskih, jedno pet-šest udovica, muževi su svi poumirali. Sad nedavno su dva brata umrli. Dva brata su bili za dvi sestre oženjeni i obadva su u roku od jedno godine dana umrli. Smanjuje se i gotovo« (M, 70, Cres, 2007).

Svojevrsni pokretači iseljavanja s otokâ početkom 20. stoljeća bili su pomorci, ${ }^{7}$ koji su ploveći svijetom upoznavali bolje uvjete života i mogućnost zarade u drugim zemljama i ta iskustva donosili na otok. Otočani su se mahom iseljavali u prekomorske zemlje (zemlje Sjeverne i Južne Amerike te Australiju $\left.{ }^{8}\right)$, i to uglavnom mlađi muškarci koji su za sobom ostavljali svoje obitelji (Lajić, 1992: 140).

${ }_{6}$ Zbog propasti nekih poljoprivrednih grana koje su bile temelj gospodarske djelatnosti otočnog stanovništva došlo je do agrarne prenapučenosti i nužnosti da se stanovništvo iseljava iz ekonomskih razloga, o čemu otočani pjesnici pišu stihove poput: »Svi su kantuni kuće kočetama ispunjeni. / Iz slamarice svake dvi tri glave viru. / Puno žlic zdila mala. / Ki će u svit šćapon doma doć umrit« (Cukrov, »Brušket«, 2009, 1: 32).

7 Pomorstvo ostaje jedna od glavnih gospodarskih grana, u kojoj se otočani zapošljavaju i nakon Drugoga svjetskog rata, o čemu svjedoči priča ispitanika s Cresa: »Onda sam '58. išo navigavat. Navigal sam skroz do penzije, do ‘91. na Jugoliniji. Sve, samo u Australiju nisam bio, drugo sam prošo, cijeli svijet. Na brodu sam bio po dvanaest-trinaest mjeseci... par mjeseci doma, i tako...« (M, 70, Lubenice, 2007).

8 Stihovi pjesme »Vapor fišća « (Cukrov, 2009, 1: 33) opisuju sjećanje na iseljavanje stanovnika šibenskih otoka u Australiju: »Vapor fišća dugo, dugo, / svima ki partiju, / najčešće put Pertha«. 
U drugoj polovini 20. stoljeća pravci emigracije, uz prekomorska odredišta, idu i prema zapadnoeuropskim zemljama i prema kopnenim urbanim središtima države - prema bližima obalnima Splitu, Rijeci, Zadru i Šibeniku, ali i dalje u unutrašnjost, najčešće Zagrebu kao najvećem urbanom i gospodarskom središtu Hrvatske. Tako na većini hrvatskih otoka traje višedesetljetno iseljavanje radno aktivnog stanovništva, primarno zbog nemogućnosti zapošljavanja na otocima, ali i zbog spoznaje da kopnena urbana središta pružaju veće mogućnosti osobnog razvoja (obrazovanje, način provođenja slobodnog vremena i sl.), odnosno višu kvalitetu života (Nejašmić, 1991; Lajić, 1992; Podgorelec i Klempić Bogadi, 2013).

Brojnije iseljavanje muškog stanovništva imalo je osobitu biološku i društvenu važnost. Posljedice su bile najvidljivije u narušenim strukturama aktivnog stanovništva, smanjenoj mogućnosti bioreprodukcije te promjenama u društvenim odnosima, formalnim i neformalnim društvenim ulogama.

Zbog malobrojnosti muškaraca u otočnim zajednicama jačaju oblici istospolne podrške (među otočankama) koji stvaraju čvrsti osjećaj zajedništva poput posestrinstva. ${ }^{9}$ Male populacije određene čvrstim granicama prostora u kojem žive, poput otočnih odvojenih morem, osjetljive su na apsolutne i relativne promjene kretanja stanovništva (Lajić i Nejašmić, 1994: 383). Primjerice u razdoblju neposredno nakon Drugoga svjetskog rata na Zlarinu zbog privremenoga ili stalnoga iseljavanja uglavnom muškaraca i njihova stradanja u ratu zabilježen je odnos dvije trećine žena naspram trećine muškaraca (Šimek-Škoda, 1951: 127-128). Među zastupljenim muškim stanovništvom najmanje ih je u radno aktivnoj dobi. Slična situacija bila je i na drugim otocima šibenskoga arhipelaga (Kalogjera, 1959: 74-75), manjim otocima zadarskog (Cvitanović, 1989: 129) i na drugim otočnim skupinama. Mnoge žene, iako formalno u braku, većinu su svog života provele bez muževa, a njihova djeca bez očeva. Naime bila je česta pojava da je muškarac nakon ženidbe odlazio u Ameriku ostavljajući ženu s nerođenim ili tek rođenim djetetom (Kranjac, 1981: 17). Jedna od mnogih životnih otočnih priča sažeta je u citatu ispitanice s Cresa: »Ja san rođena prvi novembra '21. u Podolu. (...) I ja san z mamom živela u Podolu. Bila san sama. Moj tata je dvadeset i četvrte išal u Ameriku. Ja san imala tri godine. Živel je u Bostonu, Philadelphiji, New Yorku. I tamo je umro šezdesetoga leta. Tata je pošiljal novce, (...) bil je s nami prijatelj, pisali smo si...« (Ž, 86, Cres, 2007). Tako i

9 Na Ižu i okolnim otocima nekada je bila rasprostranjena praksa sklapanja posestrinstva: „Činjenica je, da su ženske u većem broju sklapale posestrinstvo negoli muškarci pobratimstvo, jer su muškarci bili više po svijetu kao mornari ili kao iseljenici u tuđem svijetu, a ženske nisu pomične nego stoje kod kuće i k tome su brojnije od muškaraca (Cvitanović, 1956: 377). 
na Zlarinu stanovnici procjenjuju da čak trećina djece rođena oko Prvoga svjetskog rata nije upoznala oca zbog njegova trajnog boravka (ostanka) u iseljeništvu (Babić, Lajić i Podgorelec, 2004: 12).

Rijetka emigracija otočanki u razdoblju prije Drugoga svjetskog rata potvrđuje se i pričama ispitanica na zadarskim otocima (Babić, Lajić i Podgorelec, 2004). Obiteljske obveze djece prema roditeljima, posebice skrb kćeri za roditelje, najvažniji su razlog što se neke ispitanice nisu odlučile u mladosti nastaviti školovati izvan otoka ili se iseliti s otoka zbog mogućnosti zaposlenja na kopnu. Tijekom svih navedenih istraživanja čije podatke upotrebljavamo u ovome radu uzorkom su bile obuhvaćene i starije žene koje nikada nisu zasnovale obitelj, i to stoga što su odlučile (ili je to zajednica od njih očekivala) preuzeti brigu o ostarjelim roditeljima. Danas, u starosti, nerijetko žive sa sestrom udovicom ili nekim mlađim članovima obitelji (nećacima i sl.). Na pitanje jesu li ikada razmišljale otići s otoka i živjeti negdje drugdje, odgovarale su: »Nisam nikada vidila nešto bolje, pa nisam ni poželila otići«, ili »Nisam poželila nikada napustiti otok, prije nî bila moda da se ide, nego uz svoje da se živi« (Podgorelec, 2008: 161).

Mnoge tzv. »bijele udovice«, čiji su muževi bili u prekomorskim zemljama ili su plovili na brodovima raznih kompanija, uza sve uobičajene obaveze bile su primorane obavljati i teške poslove, nekada dominantno muška zanimanja, poput ribarenja, veslanja na ribarskim čamcima, sječe drva i građevinskih radova (Muraj, 1999: 226; Bara, 2013: 213). Osim u ribarenju žene su tradicionalno radile i u svim drugim otočnim poljoprivrednim djelatnostima. Razvila se svojevrsna vještina preživljavanja razvijanjem polivalentnosti funkcija uz gubljenje granica između »muških« i »ženskih« zanimanja, kao i obveza tipičnih za dob pojedinca (mladih i/ili starih), što nije bilo uobičajeno u sredinama s brojnijim stanovništvom, koje su imale preduvjete za zadržavanje specijalizacije radnih i društvenih uloga (Lajić, 1997: 26). O promijenjenim radnim ulogama žena zbog izbivanja muškaraca svjedoče otočanka i otočanin s Kaprija: »Žena sama doma i radila [je], a muž navigava, a ona u Kaprij. Sve je radila, 'eli. Prije smo i radili sve, kopali. Žene su ribarile, više nego muški, je više, više.« (Ž, 91, Kaprije, 2011) i: »Kod nas su žene sve radile, kopale vrt, masline, išle u ribu (...) Spominjao sam mojima u Marušićima ${ }^{10}$ da su žene sve radile i kopale. Nisu mi vjerovali. Tako je bilo na svim otocima [šibenskim]« (M, 75, Kaprije, 2011).

Na Zlarinu se zbog tradicionalne podjele rada, ali i stoljetne narušene

10 Naselje dvanaest kilometara južno od Omiša. 
spolne strukture te promijenjenih radnih uloga uvriježila izreka da »nije lipo vidit muškoga s motikom « ${ }^{11}$ (Jakus, 2002: 37).

Do pokretanja masovnih migracija s otoka na prijelazu iz 19. u 20. stoljeće prevladavala je usmjerenost žena na dom i poljoprivredne djelatnosti, a muškaraca na vanjski svijet, pomorstvo i ribarstvo (Muraj, 1981: 317). Usmjerenost žena na dom potvrđuju i pučke poslovice, u kojima se prepoznaje tadašnje shvaćanje društvenih uloga žena (Muraj, 1999: 221). Poslovica zabilježena na Zlarinu »Stoj, divojko, kraj komina - ni o tebi zla spomina« (Kranjac, 1981: 19) smješta ženu, u ovom slučaju neudanu djevojku, u okvire privatnosti i uske obiteljske sredine (Muraj, 1999: 221). Položaj žene razlikovao se od otoka do otoka, od naselja do naselja. Primjerice na creskološinjskom arhipelagu više je primjera ravnopravnije podjele rada, posebice kada je riječ o poljoprivrednim djelatnostima, u kojima su sudjelovali i muškarci. Tako su na Susku u vinogradarstvu žene pomagale dok su većinu poslova obavljali muškarci (Medarić, 1957: 142). Autori koji su pisali o položaju žena uočavali su znatne razlike »između onih duž obale i onih na otocima, gdje su običaji općenito blaži, a ljudi kultiviraniji« (Vince-Pallua, 1991: 81). Rodni odnosi na otocima manifestirali su se i kroz tradicijsko odijevanje (Lulić Štorić, 2010). Iako položaj žena na otocima nije bio izjednačen s položajem muškaraca, uočavaju se primjeri određene ženske samosvijesti i društvene moći. I istraživanja na Ravi, malom otoku zadarskog arhipelaga, potvrdila su kako se položaj žene na otocima preuzimanjem sve »većeg djela muških obveza zbog odsutnosti muža najčešće radi navigacije, ribarstva i iseljavanja« mijenja i postaje ravnopravniji (Lulić Štorić, 2008: 427). Pod utjecajem gospodarskih i društvenih okolnosti donekle se izmijenio tradicionalni položaj žene u patrijarhalnoj mediteranskoj sredini. U otočnim su sredinama, kao i drugdje, zadržale svoje uloge u kulturi prehrane, odijevanja i stanovanja, unoseći svojevrsnu ravnotežu s nastalom ekonomskom moći, rastućim autoritetom, mogućnošću samostalnog odlučivanja i organizacijom svih drugih domena života (Muraj, 1999: 226).

Neovisno o iskustvu česte odvojenosti od muških članova obitelji, teških životnih uvjeta, samodostatnosti u odgoju djece, a nerijetko i osiguravanja osnovnih životnih resursa, $\mathrm{u}$ istraživanjima smo naišli i na primjere nostalgije za vremenom kada su emocionalne veze između supružnika bile jake unatoč fizičkoj udaljenosti: »Svaki je poštivao svoju ženu, a žena muža. To je lipo bilo, a sad nikako. Sad ostavi muž ženu, žena muža i k vragu. Fino bilo, fino je bilo. Puno dobro« (Ž, 91, Kaprije, 2011).

11 Da je slična situacija bila i na drugim šibenskim otocima, potvrđuju stihovi pjesme »Promina stažuna« otočnog pjesnika Tonija Cukrova s Prvića: »Krešija je dan, pivaju tice, išču log. / Nabrekli pupi cicaju sok. / Podanku grede Jelena motikon priko ramena« (2009, 2: 40). 
Promatramo li podjelu rada povezanu s distribucijom moći, treba je povezati i sa specifičnom ulogom žene u mediteranskoj obitelji. Premda su »tradicionalno društvene strukture i javne politike podržavale unutarobiteljske odnose u kojima je muž i otac bio hranitelj i glavni autoritet $\mathrm{u}$ obitelji« (Moreno, 2002: 2), u malim otočnim zajednicama dogodila se značajna zamjena uloga muškarca i žene - drugačija unutarobiteljska dinamika (Podgorelec i Klempić Bogadi, 2013). Naime nakon višedesetljetnog razdoblja iseljeništva otočana mala zatvorena cjelina poput otočne zajednice teško je napuštala do tada uobičajenu podjelu rada, pa su i u slučajevima povratka muškaraca, najčešće po stjecanju mirovine $u$ inozemstvu ili završetku plovidbe, mnogi poslovi ostajali u ženskoj domeni. Tako jedan sugovornik opisuje kako i danas u starosti žena ravnopravno obavlja i one neke uobičajeno »muške « poslove zajedno s njim: »Uvečer zalijemo [vrt, masline] žena i ja. Po zimi idem na lignje. Ja i žena idemo, tu oko škoja. Žena strašno voli [ribariti]« (M, 76, Drvenik, 2007).

Osim zbog mogućnosti zaposlenja muškarci su u prvoj polovini 20. stoljeća s otoka odlazili zbog sudjelovanja u dvama svjetskim ratovima, u kojima su mnogi i poginuli, ${ }^{12}$ a žene su se i zbog toga ostajale same brinuti o djeci te o svojim, ali i suprugovim roditeljima. Jedna sugovornica prisjeća se uloge svoje bake u očuvanju obitelji koja je privremeno ostala bez muškarca hranitelja: »Po ocu je baka bila iz Malog Lošinja, koja se je udala u Sveti Jakov devetstote. I onda je došla živit tamo i imali su šestero djece. Jedno je umrlo na početku Prvog svjetskog rata i djed je morao ić u vojsku i ostavit mrtvo dijete $u$ kući. I bio je šest godina u ratu. Zapravo bio je četiri, a dvije u zarobljeništvu. Ali vratio se živ i zdrav '20. doma. Baka je brinula za svih. U to vrijeme bio je mukotrpan život jer su morali brinuti se za hranu« (Ž, 69, Lošinj, 2007). Dio žena ravnopravno je sudjelovao s muškarcima u Drugome svjetskom ratu, o čemu je svjedočila jedna od najstarijih sugovornica: »Rođena sam na dva prvoga, dvadesete [2. siječnja 1920.]. Bila sam u ratu stariji vodnik. U ovome našemu Titovu, eee [potvrdno]. Mi smo ode bili na otoku, iz Binjuša bi vozili ranjenike i hranu na Žirje, a iz Žirja hranu i gorivo pod Binjuš. I onda bi Nijemci zapucali pod Binjuš i utopili se naši u more« (Ž, 91, Kaprije, 2011).

Drugi val masovnog iseljavanja s otoka počinje nakon 1945. i povezan je $\mathrm{s}$ industrijalizacijom zemlje, razvojem obalnih gradskih središta te sve ve-

12 Stihovi »Spram tujih soldato, u jatu su za slobodu, sa ribanja zaveslali. / Malo posli, u jednom su danu pali, njih trideset na Sutjeski, golobradih sa Prvića (Cukrov, 2009, II: 34) potvrđuju velika stradanja stanovnika malih dalmatinskih otoka (primjerice šibenskih otoka te zadarskih Iža i Dugog otoka), koja su značajno utjecala na kasniji demografski razvoj (depopulaciju) lokalnih zajednica i današnju brojčanu dominaciju starih žena. 
ćim gospodarskim zaostajanjem otokâ. Iako se prekomorska emigracija nastavlja, važna odredišta postaju gradovi - od bližih obalnih do većih gospodarskih središta u ostalim dijelovima Hrvatske i Jugoslavije. Za razliku od prethodnih razdoblja, u poratnim godinama žene u većem broju sudjeluju u migracijama i ravnopravnije se uključuju u tržište rada (Graovac, 2004: 188-189). Višedesetljetno masovno odseljavanje mladih muškaraca i veliki ratni gubici muškog stanovništva poremetili su mogućnost zasnivanja obitelji na otocima, što je uzrokovalo višak mladih neudanih žena (Kranjac, 1981: 13). To je za posljedicu imalo smanjenje rodnosti, a ubrzo i pojačano iseljavanje mladih žena, koje su bračne partnere nalazile izvan otoka. Sugovornica sa Žirja tako svjedoči: »Ove žene [pokazuje u smjeru starijih žena], sve su to naše žene. One su bile u ratu pa su se udale za vojna lica, pa su dobile stanove u Zagrebu, Zadru, Splitu, Dubrovniku svugdi i sad se vratu preko lita, eto « (Ž, 74, Žirje, 2011). Na zadarskim otocima s narušenom spolno-dobnom strukturom (primjerice Ižu i Dugom otoku) žene su tijekom poratnog razdoblja sudjelovale $u$ emigraciji čak i u nešto većem broju od muškaraca (Babić, Lajić i Podgorelec, 2004: 52-53). Osim spomenutih migracija zbog udaje, razloge sve brojnijeg iseljavanja žena valja tražiti u boljim mogućnostima obrazovanja i zapošljavanja, ali i ukupnoj kvaliteti života dostupnoj u urbanim središtima na kopnu. Tako sugovornica s Cresa govori o svom iskustvu: »Onda sam '48. doznala da je primaljska škola u Rijeci. Imala sam devetnaest godina. I tata je bio za to da idem dalje, ali žao mi je bilo mamu pustiti. Tata, nono i troje braće su ostali kući [tuga u glasu]. Ja sam se spremila i na magarcu tata me je odnesel u Osor na brod. Plačuć sam išla. Bila sam na jednu stranu vesela da idem u školu. Išla sam tamo i teško mi je bilo« (Ž, 78, Cres, 2007). Poslije završenog školovanja dio mladih žena vraća se na otok, i to uglavnom na srednje i velike otoke, s više naselja i s većim brojem stanovnika, poput Krka, Cresa i Lošinja, na kojima mogu naći posao: »I '50. sam išla u Lošinj raditi kao babica. Poslali su me na Sansig [Susak] primat neki porod. I nakon nekog vremena, babica koja je bila tu [u Cresu] je išla u Ameriku i javili su mi da moram ići u Cres raditi« (Ž, 78, Cres, 2007).

Bolje mogućnosti obrazovanja omogućivale su i lakši pristup tržištu rada izvan otoka. Budući da se ženska djeca od 1960. u podjednakom broju obrazuju kao i muška, u jednakom se broju i trajno iseljavaju s otoka, što nam potvrđuju sljedeće riječi: »Kćeri, kad su otišle na škole u Rijeku, više se nisu vratile. One rade u Rijeci. Jedna je medicinska sestra, jedna je konobarica, jedna je u Rafineriji - radi kao činovnica, a jedna je u Crikvenici« (M, 70, Cres, 2007). 
Informacije o boljim uvjetima života te nepostojanje čvrste socijalne kontrole izvan otoka, izražene u malim otočnim zajednicama, također su bili svojevrsni poticajni čimbenik na seljenje sve većem broju mladih žena. Tako ispitanica $\mathrm{u}$ istraživanju na šibenskim otocima, umirovljena otočanka (Zlarin, 74, 2011) koja je cijeli radni vijek provela u Zagrebu, ističe koliko je željela zaposlenje na kopnu kao mogućnost ostvarenja samostalnosti i bijega od običajâ i zahtjevâ otočne sredine: »Rođak mi je našao posao u Zagrebu, jedva sam čekala otići s otoka. Znala sam, ako ostanem, da ću se morat brzo udati, a onda nikad neću otići« (Podgorelec i Klempić Bogadi, 2013: 33).

Dio otočnih zajednica u razdoblju nakon Drugoga svjetskog rata obilježilo je i iseljavanje optanata. Tako se dio otočana, posebice s kvarnerskih otoka, trajno iselio u Italiju: »Kad je bila privredna reforma, htjeli su [država] to [posjede] oduzeti. Onda su sestre i braća moje mame otišli ća, u Italiju. Ostali su samo mama i dva strica. Jedan stric je ostao na zemlji i umro je rano, a drugi, koji je umro prije petnaest dana, bio je zadnji od te generacije. I tako, ostali rođaci [od njih 24], svi su otišli. (...) Sjećam se ko da je danas, 10. srpnja 1950., imala sam dvanaest godina, cijeli dan sam plakala jer je cijelo moje društvo iz Svetog Jakova otišlo. Bilo je baš iz Svetog Jakova otišlo jedno šest-sedam obitelji s djecom. Prijatelji su mi svi otišli u Italiju. I ostali su živjeti. Dođu danas neki ljetovati, dođu i njihova djeca. Neki su i prodali kuće, a neki nisu. A poslije je nešto išlo [emigriralo] i u Ameriku« (̌̌, 69, Lošinj, 2007).

Neplaćeni rad žena, ali i sve druge aktivnosti kojima su se bavile bili su izvor ekonomskog održanja i glavni izvor društvene kohezije obitelji, ali i zajednice u cjelini, u prošlosti i danas. Oduvijek su, već kao djevojčice, na otocima morale puno i vrijedno raditi, a tu radnu etiku zadržale su i u starosti: »Ma ja sam morala kući radit. '52. se moj tata razbolio od tuberkuloze. I ja sam morala ujutro, prije nego idem u školu, ustat se u četri ure, poprskat vinograd, doć doma oprat se i iz Svetog Jakova u Nerezine još dva i pol kilometra pješačiti, ić u školu. I nije to bilo dosta. Nego poslije nastave bi išla kod jedne tete, bi bila jela ono što sam donijela - moj ručak u jednoj padelici, i otišla u šnajderaj jer je žensko dijete moralo nešto znati još. A ja to nisam baš volila. I navečer, ako je trebalo ići pomust ovce, ja s biciklom i odoh u brdo. Zato meni samo učenje i škola - to je bila pjesma. Zato mi i danas nije ništa teško raditi. Ja sam od jako-jako vrijedne obitelji, radne, i s mamine is tatine strane« (Ž, 69, Lošinj, 2007).

Znanstvenici koji se bave prostorom Mediterana zamjećuju da su demografske promjene u posljednja tri desetljeća, za razliku od događanja u drugim dijelovima Europe, ojačale ulogu obitelji, koja je i dalje glavni izvor 
materijalne sigurnosti ${ }^{13}$ svojih članova, središnja institucija socijalizacije i predstavlja čvrstu mrežu mikrosolidarnosti. U očuvanju kvalitete života obitelji značajnu ulogu odigrale su, kako ih primjerice naziva Luis Moreno (2002), »superžene« koje se uz brojne neplaćene kućanske poslove, rad na okućnici i sl. sve češće i profesionalno zapošljavaju.

\section{OSTARJETI NA OTOKU -ŽENSKA PERSPEKTIVA}

Društveno starenje pojam je koji obuhvaća različita iskustva koja pojedinci proživljavaju prolazeći kroz različite etape života, preuzimajući određene uloge i stvarajući odnose s drugim ljudima, ali i kao članovi širih društvenih struktura. Kroz individualno iskustvo društveno starenje utječe na percepciju »tko sam«, a kao konstrukt društvenoga i kulturnoga konteksta diktira normativna očekivanja u vezi s ulogama, položajem i ponašanjem starijih osoba u društvu (Phillips, Ajrouch i Hillcoat-Nallétamby, 2010: 13).

$S$ obzirom na njihovo iskustvo (ne)migriranja, a prema nalazima provedenih istraživanja, danas je na hrvatskim otocima u tzv. generaciji starijih stanovnica moguće razlikovati četiri skupine: otočanke (»nemigrantice«) koje nisu nikada (na duže vrijeme) napuštale otok; otočanke koje su dio obrazovanja i najčešće cijeli radni vijek provele izvan otoka, a po umirovljenju se vratile živjeti na otok; doseljenice iz drugih dijelova države ili iz inozemstva, koje su na otok došle zbog zasnivanja obitelji; i zasad relativno manju skupinu neotočanki ${ }^{14}$ koje veći dio godine ili stalno žive na otoku, a pripadaju skupini migranata umirovljenika ili migranata životnih stilova. Istraživanja su potvrdila da zajednički uvjeti života na otoku (klima, more, uvjeti za gospodarsku djelatnost - prije svega poljoprivredu, razina povezanosti otoka s kopnom, kvaliteta zdravstvene skrbi, lokalni običaji i dr.) utječu na neka njihova zajednička iskustva u starosti, dok razlike u važnim događajima tijekom pojedinačnih životnih ciklusa, a koje u znatnoj mjeri određuje (ne)iskustvo osobnog migriranja, odnosno provođenja radnog razdoblja života izvan otoka, uvjetuju razlike u načinu života.

Istraživači su instituciji umirovljenja uvijek prilazili više kao muškom pitanju, dok su se istraživanja utjecaja smrti supružnika uglavnom bavila

13 Koliko je god gospodarska, a onda i materijalna situacija stanovništva manjih hrvatskih otoka teška (starije stanovništvo koje pretežno živi od mirovina, relativno nerazvijen turizam, neadekvatna opskrba, više cijene u otočnim trgovinama, odnosno ukupno viši troškovi života nego na kopnu), otočne obitelji uglavnom uzdržavaju i/ili pomažu svoju djecu na kopnu, kao što navodi sugovornica na Zlarinu $(65,2011)$ : »Djeca dolaze iz interesa na otok, dolaze po novce, ribu, hranu. Roditelji ih uzdržavaju.«

14 Riječ je uglavnom o mlađim starim ženama (između 65 i 75 godina). 
ulogom udovica (Calasanti i Zajicek, 1993). Potvrđuje se da će udane žene, za razliku od neudanih, češće ranije otići u mirovinu zbog oslonjenosti na prihode - suprugovu plaću ili mirovinu. U mirovini će se starije žene u odnosu na starije muškarce vjerojatnije susresti s ekonomskim nejednakostima i poteškoćama (Higo i Williamson, 2009: 332). ${ }^{15}$

Jedna od važnijih razlika između navedenih skupina starih otočanki njihov je socioekonomski standard. Naime izvor prihoda tijekom radnog razdoblja temelj je sigurnosti prihoda u starosti, pa ovdje značajnu razliku u načinu, a onda i kvaliteti života zatječemo ovisno o tome žive li u samačkim kućanstvima ili s nekim članom obitelji, jesu li bile zaposlene ili kućanice te izvoru i vrsti prihoda od kojeg žive (osobna ili starosna mirovina, bavljenje turizmom, prihodi doseljenih ${ }^{16}$ - inozemne mirovine, socijalna pomoć za one koje nisu ostvarile pravo na mirovinu i sl.).

Sugovornice $u$ istraživanjima navode različitu razinu životnog standarda ovisno o tome žive li u višečlanome, najčešće dvočlanome, kućanstvu s više izvora prihoda: „Sedamnaest godina je da sam u mirovini. Imam 2500, a muž ima malo manje od 3000. Onda on ima i talijansku mirovinu, 2400 u kunama, a u eurima 328. (...) Smo puno toga mi napravili. Čamac kupili, i garažu (...) onda ovu kuću (...).«(Ž, 78, Cres, 2007) ili pak samo s jednim prihodom (starosnom mirovinom) - »Mirovina je mala, ni nam dovoljna. A šta dobin, dvi hiljade. Žena mi nije nikad radila. Mlada je obolila, sa 24 godine. Živimo od jedne penzije i ovo što radimo. A djeca mi ne pomažu, ja još njima [smije se]«(M, 76, Drvenik Veli, 2007). Primjer oslonjenosti na mirovinu supruga i ekonomsku nesigurnost zbog niskog prihoda navodi i sugovornica s Kaprija: »Nisam imala svoju mirovinu. Muž mi je bio oficir u Dubrovniku. Živili smo u Dubrovniku, vrag zna koliko, ja mislim da je bilo sedam-osam godina. Ne bi ti znala reći kad sam se vratila, 1956. ili 1957. Zaboravila sam više. [istraživač: 'Je li Vam mirovina dovoljna za Vaše potrebe?'] Ha, čuješ. Bilo bi bolje da je više. Lijekovi su skupi. Da nije lijekovi, eee [uzdah]. Kupiš lijekove i ne ostane ti ništa, eto šta je« (Ž, 91, Kaprije, 2011). Na pitanje kada je posljednji put otišla do Šibenika, sugovornica s Kaprija ${ }^{17}$

15 Većina žena radila je na slabije plaćenim poslovima tijekom radnog vijeka, pa su njihove mirovine niže nego one muškaraca. Brak i majčinstvo također povećavaju nejednakost (u smislu diskontinuiteta radnih uloga), dok su razlike manje za neudane žene. Usporedba stope siromaštva muškaraca i žena u Hrvatskoj prema dobnim skupinama pokazuje da se značajnije razlike između siromaštva muškaraca i žena pojavljuju tek u starijoj dobnoj skupini koja pripada umirovljeničkoj populaciji (Šućur, 2011: 248).

16 U skupini starijih doseljenica, migrantica životnih stilova, nailazimo na razliku u životnom standardu, ali uglavnom je riječ o dvočlanim kućanstvima s dobrim prihodima, odnosno stabilno situiranoj skupini stanovnika.

17 Liječnik obiteljske medicine dolazi na Kaprije jednom tjedno, a na otoku živi medicinska sestra. 
odgovara: »Bit će jedno prije pet-šest mjeseci zbog doktora. Teško je, teško je ići u grad, nema se, sredstava «(Ž, 91, Kaprije, 2011).

Mnogo je starijih otočanki koje tijekom života nisu bile zaposlene, a žive u samačkim kućanstvima od obiteljske mirovine, kao sugovornica s Cresa: »Ja imam mirovinu, ali malu... imam mirovinu tisuću i pedeset [kuna]. Ne moren živit samo od mirovine. Deca pomognu« (Ž, 86, Cres, 2007). Solidarnost članova otočnih zajednica, koja olakšava život u starosti, ogleda se i u naturalnoj razmjeni onih koji imaju svoje proizvode iz vrta ili maslinika s drugima koji love ribu ili sijeku drvo za ogrjev. Primjer je takve međusobne pomoći i izjava sugovornika sa Silbe koji kad god mu to vremenske prilike i zdravlje dopuštaju, odlazi u ribolov: »U prosjeku na jedan izlazak se uvati dva kila, tri kila. I za sebe jesti imate! Ne interesira me prodaja. Ne, ali dajem prijateljima. Starijima koji nemaju nikoga, koji ne mogu ići na ribe. Većinom ženske. Onda im dajem po dvi ribice za lešo, ovim dvi za pofrigati, dvi za brudet. Ribe podilim dosta. (...) A onda one meni daju zelje [smijeh]. I tako uzajamno« (M, 76, Silba, 2003).

Uloge pomažu definirati proces starenja i sredstvo su tranzicije tijekom životnog ciklusa, pružaju normativne smjernice kako bi se pojedinci u određenome društvenom statusu mogli nositi s očekivanjima tijekom pojedinih životnih razdoblja (Ferraro, 2001). »Usprkos značajnim promjenama u zdravlju, funkcioniranju i društvenim okolnostima, veliki dio starijih odraslih osoba tijekom vremena pokazuje znatnu dosljednost u svojim obrascima razmišljanja, aktivnostima, načinu stanovanja i društvenim odnosima « (Atchley, 1999: 1). Kada je riječ o starijemu otočnom stanovništvu, fizički rad izvan kuće uglavnom nije u većoj mjeri rodno obilježen, za razliku od načina provođenja dokolice. ${ }^{18}$ Naime klima, tlo i more uvjeti su koje svi podjednako nastoje iskoristiti, pa se tako i muškarci i žene bave raznim oblicima poljodjelstva (vrtom, okućnicom, radom u polju, maslinarstvom, vinogradarstvom, ribolovom i sl.) kao izvorom dopunskog prihoda za kućni budžet, odnosno kao načinom provođenja poluslobodnog ${ }^{19}$ vremena. Poljoprivrednim djelatnostima (primjerice povrtlarstvom ili uzgojem maslina) s jednakim se elanom bave autohtone otočanke kao i novodoseljene starije stanovnice otoka: »Za moj gušt je vrt. (...) U njemu imam svašta, voće i povrće. Imamo vodu provedenu, kapanje, izraelski sistem (...) imam nektarinke,

18 Stariji muškarci znatno više vremena provode u međusobnom druženju izvan kuće, dok se ženin prostor i poslovi još uvijek u prvom redu vežu uz dom (Podgorelec, 2008; Podgorelec i Klempić Bogadi, 2013).

19 Vrijeme koje nije isključivo dokolica, već je djelomice i obveza, a donosi i određenu materijalnu korist pojedincu (Podgorelec, 2008: 127). 
naranče, limune... Sve smo to mi sadili, isplanirali. Imamo svu verduru, kupus, tikvice, luk, salatu... Sad će početi pomidori, kukumari. To za moj gušt, za moju dušu« (Ž, 69, Mali Lošinj, 2007).

Pojedinci imaju tendenciju da stare na načine koji su konzistentni s obrascima osjećaja i ponašanja iz ranijih životnih razdoblja. Žele zadržati postojeće obrasce unatoč izraženim promjenama u osobnoj okolini, bilo da je riječ o njihovim životima tijekom starenja ili o društvenim promjenama. Tako i sugovornica otočanka koja je radni vijek provela izvan otoka kaže: »Tu živim cili život i da me netko makne i na Prvić bilo bi mi teško. Naučila sam se i u Šibeniku, ali sam svaku subotu uvijek dolazila na Zlarin i sad se [u mirovini] vratila za stalno« $(\check{Z}, 62$, Zlarin, 2011).

Ako je osoba aktivna društveno, mentalno ili fizički u razdoblju srednje zrelosti, vrlo je vjerojatno da će takvu razinu aktivnosti zadržati, pod uvjetom da joj to omogućuje njezino zdravstveno stanje, i u kasnijem životnom razdoblju. Takav obrazac ponašanja predstavlja dio osobnog identiteta starijeg pojedinca i jača njegovo samopoštovanje. Održavanje uobičajenih aktivnosti implicitno je i standard normalnog starenja. Temeljno obilježje načina života stanovništva hrvatskih otoka, potvrdila su sva navedena istraživanja, aktivni je životni stil i oslanjanje na vlastite snage do duboke starosti. Sugovornica s Cresa potvrđuje: »Kupin sama, skuhan sama, pometen kuhinju sama, krevet napravin i sve sama. Niko mi ne dolazi. Kada god (...) ne znam ko, počisti malo, ma ne, ne trebam. (...) ja napravin sama (...) ja mogu sve sama. A niš me ne muči, sada samo starost « (̌̌ $, 86, C$ res, 2007).

$S$ obzirom na višedimenzionalnost definicija pojma aktivnog starenja, a imajući u vidu specifičnosti uvjeta u kojima živi stanovništvo manjih otoka, zalažemo se za definiranje razine aktivnosti koja nadilazi fizička ograničenja osobe (ograničenja zbog opadanja razine zdravlja, odnosno tjelesne snage vezane uz starenje), odnosno pri određivanju stupnja aktivnosti pojedinca značajno je razmotriti razinu samostalnosti (životni stil stare osobe), ali i potrebe za participacijom u zajednici (koja je uglavnom, kako potvrđuju sva navedena istraživanja, iznimno visoka u malim zajednicama) (Podgorelec, 2008; Podgorelec i Klempić Bogadi, 2013; Bara, 2013).

No kontinuitet životnih stilova i društvenih uloga gotovo je nemoguće potpuno zadržati s obzirom na neizbježnost gubitaka tijekom života potaknutih događajima poput značajnijeg narušavanja zdravlja, smrti bliskih osoba, odlaska djece iz obiteljskog doma, odlaska u mirovinu i sl.

Upravo takav primjer prekida kontinuiteta $\mathrm{u}$ aktivnostima zbog zdravstvenih tegoba, slabosti i nemoći, što je često u skupini najstarijih stanovnika, navela je sugovornicu s Kaprija da na pitanje prakticiraju li još uvijek 
stari otočani rad u vrtu, odgovori: »Auu, kad je to bilo, davno, to smo otpisali. Prije smo radili sve i kopali. Sad je sve zapušteno. Mladost neće da ide, a starost ostarilo i tako je sve u ledini. Na Kaknju smo mi imali lozu, maslinu, svega... Ostalo je maslini, ali sve je to u ledini. To niki ne kopa, ne radi $«\left(\check{Z}, 91\right.$, Kaprije, 2011). ${ }^{20}$

Život na otoku nužno zahtijeva putovanje s otoka na obližnje kopno, posebice kada znamo da na manjim otocima nedostaje kvalitetna i redovita zdravstvena zaštita, rijetka je opskrbljenost kućnim potrepštinama te su cijene namirnica visoke. Sa starošću opada razina pokretljivosti i s obzirom na dob (unutar razdoblja starosti) i s obzirom na funkcionalni status, pa tako otočanke stare 80 i više godina žive potpuno ili djelomice samostalno, pri čemu su neke prisiljene ovisiti o pomoći drugih, odnosno lijekove i potrepštine dostavljaju im mlađi članovi obitelji, prijatelji ili susjedi.

Zbog promjena koje su se dogodile prije svega unutar suvremenih obitelji (smanjenje broja članova, odvojeno stanovanje, ravnopravno obrazovanje i zaposlenost žena i sl.) stari su ljudi danas izloženi većem riziku nego prijašnje generacije da neće imati nikoga tko bi im pružio pomoć i njegu u njihovu domu. Situacija na hrvatskim otocima slična je drugim otočnim sredinama na Mediteranu (usp. Troisi, 2013: 276). Pritom valja naglasiti da su uloge pružatelja bilo kojeg oblika neformalne skrbi još uvijek u velikoj mjeri rodno usmjerene. Primjerice dugotrajna skrb za starije osobe u velikoj mjeri ovisi o neplaćenom radu žena koje tu skrb pružaju (supruge, kćeri, druge članice obitelji, prijateljice), ali i profesionalkama, koje su nerijetko potplaćene (medicinske sestre, osobne pomoćnice) i uglavnom »nevidljive« (Hooyman, 2002: 488). I u otočnim zajednicama još su uvijek znatne razlike u očekivanjima tko treba biti glavni pružatelj skrbi ostarjelim roditeljima. Sva navedena istraživanja na uzorku stanovnika hrvatskih otoka potvrdila su da u starosti otočanke uglavnom računaju na pomoć članova obitelji, u prvom redu bračnih partnera (ako ih imaju), a onda djece, i to, prije svega, kćeri. Tako jedna sugovornica svoj život procjenjuje dobrim zato što se kći skrbi za nju: »Mladost je dobro prošla, a i starost. Gledaju me dica, dobra je i starost i mladost. Kći mi je četrdeset i prvo godište. Penzije nema, nije radila nigdi, samo od muža« (Ž, 91, Kaprije, 2011). Ili kako objašnjava otočanka koja je radni vijek provela u Šibeniku i vratila se na Zlarin: »Mama je bila bolesna i to je razlog zašto sam se povukla na otok« (̌̌, 61, Zlarin, 2011).

20 Istu situaciju zapuštenosti poljoprivrednih površina, koje preostalo staro stanovništvo zbog raznih tegoba i nemoći ne može obrađivati, opisala je i sugovornica sa Žirja: »Oko kuće još mogu, a u polje ne idem. Tamo sada nema više ništa. Da sad idete kroz naše polje i da vidite šta je to, a prije se to sve kopalo.« (Ž, 74, Žirje, 2011) (usp. Faričić i Magaš, 2004: 137). 
Svijest o nužnosti organiziranja raznih oblika formalne skrbi za brojno starije otočno stanovništvo postoji posebice u skupini mladih starih otočana i starijih doseljenica koje imaju iskustvo života u urbanim zajednicama, među kojima se sve rjeđe čuje uobičajena rečenica starijih starih otočanki: »Mojim bi bila sramota da bi ja išla [u dom]«(Ž, 86, Cres, 2007). Tako primjerice sugovornica medicinska radnica u mirovini procjenjuje: »Ima puno starih ljudi, ali dom se sada otvorio, bit će godina i pol. U domu ih je sedamnaest, ali ima još zainteresiranih. Više nije sramota ići u dom. Pomalo, ljudi su se smirili. Vidiju da je to baš lijepo. Prije bi se bili čudili, ali sada je postalo kao normalno« (̌̌, 78, Cres, 2007).

Budući da je za stanovništvo tradicionalnih zajednica, poput otočnih, prihvatljivije rješenje da se starijim članovima bilo koji oblik pomoći i skrbi pruža u prostoru njihova doma, iznimno se uspješnim pokazao projekt »Dnevni boravak i pomoć u kući starijim građanima «, ${ }^{21}$ koji se odvijao na šibenskim otocima od 2006. do 2013. U skladu sa spomenutim očekivanim rodnim usmjerenjem određenih poslova na otocima, u projektu pomoći $u$ kući stvoren je tim gerontodomaćica, dakle isključivo žena bez traženoga formalnog zanimanja, bez edukacije za pružanje osnovne zdravstvene skrbi, koje su starijim korisnicima dostavljale lijekove i namirnice, pomagale im u održavanju osobne higijene i čišćenju stambenog prostora ili pružale pomoć pri prijevozu. Iznimno važan segment njihova rada bio je i socijalni kontakt: razgovor i druženje s korisnicima. Najveći broj korisnika usluga gerontodomaćica bile su starije otočanke koje žive u samačkim kućanstvima.

Kvaliteta života u starosti u znatnoj mjeri ovisi o uključenosti pojedinca $\mathrm{u}$ život zajednice na bilo koji način. U malim otočnim zajednicama kontakti su relativno redoviti i bliski, članovi se međusobno pomažu. Posebice su odnosi u zajednici važni zbog velikog broja samačkih kućanstava. Istraživanja (Babić, Lajić i Podgorelec, 2004; Podgorelec, 2008; Podgorelec i Klempić Bogadi, 2013: 130) potvrdila su da je na hrvatskim otocima otprilike svako četvrto kućanstvo jednočlano, a da broj jednočlanih staračkih kućanstava raste što je promatrano naselje manje, prosječna starost stanovnika viša i prometna povezanost otoka slabija. Tako sugovornica (71) iz Mulina na Ugljanu slikovito opisuje: »Žarulje gore pticama, jer je u kućama samo po koji starac«( $\check{Z}, 71$, Ugljan, 2001).

Kao i u drugim mediteranskim zemljama, i na hrvatskim otocima u staračkim samačkim kućanstvima u znatno većem broju žive starije žene. Nai-

${ }_{21}$ Projekt Grada Šibenika i Ministarstva obitelji, branitelja i međugeneracijske solidarnosti. 
me razlike u očekivanjima spram uloga koje preuzimaju ili zadržavaju žene i muškarci u otočnim zajednicama $u$ trenutku određenih gubitaka tijekom životnog ciklusa značajne su i teško se mijenjaju. Tako je i među starijim otočanima nerijetko veći broj udovica ${ }^{22}$ nego udovaca. Osim bioloških čimbenika (dugovječnosti žena) te razlike na hrvatskim otocima pojačavaju posljedice migracija iz prijašnjih razdoblja te izravni ratni gubici ${ }^{23} \mathrm{u}$ Drugome svjetskom ratu (Graovac, 2004: 200), ali i običaji koji generaciji starijih žena »nameću ostajanje u statusu udovištva«. Naime žene su u znatnoj mjeri samostalnije i lakše se nose s uobičajenim zadacima svakodnevnog života i kada ostanu same, a od njih se i više očekuje na području pružanja pomoći djeci i brige za unuke nego od starijih udovaca (očeva i djedova).

Sugovornica na Žirju koja po dobi pripada u skupinu mladih starih kaže: »Sama živim, svi su mi sa Žirja vani« (Ž, 74, Žirje, 2011). Osjećaj osamljenosti, zbog osobnih gubitaka ili gubitaka društvenih kontakata, čest je u starijih ljudi. U otočnim zajednicama uzrok osamljenosti starijih nerijetko je sukob između sjećanja na idealizirane odnose i način života obitelji i zajednice u vrijeme njihove mladosti te današnjih obiteljskih odnosa i vrijednosti, nekadašnjih brojnih obitelji i otoka na kojima je živjelo mnogo mladih nasuprot današnjim brojnim jednočlanim kućanstvima i malobrojnim zajednicama u kojima žive pretežno stariji ljudi. Tako 77-godišnja sugovornica s Iža čiji sin živi u Njemačkoj i dolazi jednom godišnje u posjet, a kći koja živi u Australiji nije ju posjetila već sedam godina, kaže: »Ova pustoš više nije onaj Iž, ko da sam s Marsa pala u grobnu tišinu... Spremila sam robu za ukop, a ključ ostavljam s vanjske strane vrata da ljudi ne moraju provaljivati kad umrem« (Klempić Bogadi i Podgorelec, 2002: 335).

Razina osamljenosti u starosti umnogome ovisi i o prijateljstvima izgrađenima tijekom radnog vijeka pojedinca ili razdoblja brige za djecu, ulogama koje su najčešće nosile žene, a koje i dalje utječu na karakteristike i značenja prijateljstava u kasnijem životu (Arber, Davidson i Ginn, 2003: 4). Taj je odnos u malim otočnim zajednicama, u kojima svatko svakoga poznaje »cijeli život«, dakle i u vrijeme prije odlaska s otoka zbog školovanja

22 Istraživanja potvrđuju da je među starijom populacijom u dobi od 65 do 69 godina $34 \%$ udovica, a samo $7 \%$ udovaca, dok je u skupini deset godina starijih, od 75 do 79 godina, čak 60\% udovica i samo 18\% udovaca (Sweet i Bumpass, 1987, u: Perlmutter i Hall, 1992: 330).

23 Sugovornica koja je sudjelovala u Drugome svjetskom ratu svjedočila je brojnim stradanjima mladih otočana: »A da vidite vi, tila sam još ovo reći, a naši bi kad bi odili pod Binjuš s brodom i Nijemci bi i' dočekali i pucali, a pun brod bija vojske. Naši bi vozli doli na Žirje i oni bi zapucali i naši bi ti bili u brodu i ti bi se utopili u more, jeli vojska, partizani. Vojska bi poginula sva, u moru bi stajala onako. Puno odegi nas naroda je čuda vidila u partizanima« (Ž, 91, Kaprije, 2011). 
ili zapošljavanja, kao i nakon povratka na otok, najčešće po umirovljenju, naglašen. Čvrsta mreža solidarnosti, ${ }^{24}$ o kojoj svjedoče otočani, i bliskost koju osjećaju potvrđuju važnost prijateljstva i u starosti. Tako sugovornici objašnjavaju: »Živim punim plućima. Izađem iz kuće i odmah me netko pozdravi. Prisnost življenja ko u komuni.«(Ž, 61, Zlarin, 2011); »Srdačnost, prisnost, ako i ne mogu pomoći [sumještani, prijatelji], saslušat će, suosjećat će.« (M, 61, Zlarin, 2011); »Suživot poštenja, sigurnosti, pomaganje, razumijevanje i druženje.«(M, 60, Zlarin, 2011); »Pripadnost zajednici, upućeni [smo] sami na sebe.«(Ž, 65, Zlarin, 2011); »Solidarnost, cijelo mjesto je kao familija« (̌̌, 60, Zlarin, 2011). Sugovornica sa Zlarina $(61,2011)$ o slobodi i ispunjenosti otočnog života, kojem značajno pridonose socijalni kontakti u zajednici, kaže: »Kako me život pita, tako živim: šetam, čitam, jako volim kuhati, TV, druženje i s mlađima i sa svećenikom, svi smo kao jedna familija«. I ispitanica na Kaprijama naglašava važnost susjedstva i međusobnog posjećivanja: »A kako, evo ovako, sidin, niki te pozove i ja kod drugoga $\mathrm{i}$ tako. E, kako nije, odu jedan kod drugoga. Svaki pomogne jedan drugomu« (Ž, 91, Kaprije, 2011).

Značajno mjesto u životima otočanki, kako mladih starih tako i starih starih, bez obzira na veličinu naselja, brojnost stanovništva ili stupanj razvijenosti otoka, zauzima vjera, kojoj posvećuju znatni dio svakodnevice i koja mnogima predstavlja čvrsto uporište : »Onda u osam sati, ako je misa u osam, iden u crkvu na misu (...) I to ti je moje. (...) ujutro mi je drago pojt u crkvu... Onda, navečer još iden u crkvu, u sedam. (...) ja se iden pričestit. To je mene svaki dan.«(Ž, 86, Cres, 2007); »Po zimi se dižem oko šest, šest i kvarat i onda pola do tri četvrt sata molim. Najbolji dio dana posvetim Bogu. Onda idem na misu, to bude sedam i pol ili u osam. (...) [Ljeti] [u] stanem ujutro u pet i pol. Isto, pola sata minimalno molim, to se Gospodinu posveti.«(Ž, 69, Mali Lošinj, 2007); »I tako mi je drago ići na misu navečer u crkvu. U sedam sati. Idem kod franjevaca ili u glavnu našu. To gledam tako svaki dan ići. To mi radi zadovoljstvo. Ja svih poznam i svih volim, (...) sa svima sam dobra. Malo popričamo poslije mise« (Ž, 78, Cres, 2007). Dakle religioznost je na otocima blisko povezana s tradicijom, a predstavlja

24 Intenzitet socijalnih kontakata u takvim malim, pretežno ruralnim zajednicama snažniji je, bez obzira na to je li riječ o bliskosti, međusobnom pomaganju, solidarnosti, druženju ili pak razmiricama i sukobima. Naime razina privatnosti u maloj otočnoj zajednici relativno je niska i, kao što objašnjavaju ispitanici: „Svak o svakome zna sve, neograničena znatiželja i svak svakome kaže svašta, ništa nas ne može šokirati« (Ž, 48, Zlarin, 2011); »Sve su lipe riči, a kad izađete, ogovaraju. (M, 51, Ugljan, 2004); "Zatvoreni su, svoje neće reći, a tuđe sve hoće znati« (Ž, 71, Lošinj, 2008), a o tome slikovito i pomalo ironično govore i stihovi: »Na selu se govori: sa ticon, sa pason, sa maškon, beštijama redon, / ali ne sa susidon « (Cukrov, 2009, 2: 44). 
i oblik druženja, posebice ženama. Naime promatranja učestalosti i redovitosti sudjelovanja u raznim aktivnostima vezanim uz crkvu poput odlaska na misu, uređenja crkve, pjevanja u zboru ili redovitih zajedničkih moljenja krunice potvrdila su da otočanke u znatno većem broju odlaze u crkvu negoli otočani i da je to mnogim starijim starim (starijima od 80 godina) otočankama jedini organizirani oblik provođenja »slobodnog vremena « izvan doma. Navedeni primjeri potvrđuju da su društvene aktivnosti i participacija u zajednici važan čimbenik u ostvarenju uspješnog starenja (Rowe i Kahn, 1997: 439). Iako je za zdravo i uspješno starenje važno očuvanje tjelesnih i kognitivnih funkcija pojedinca, socijalni gerontolozi (Minkler i Fadem, 2002: 229) u promoviranju više kvalitete života apostrofiraju društveni angažman pojedinca neovisno o prirodi aktivnosti.

\section{ZAKLJUČAK}

Starenje i feminizacija starog stanovništva hrvatskih otoka uznapredovali je proces, nastao prije svega kontinuiranim iseljavanjem radno aktivnoga i u ranijim razdobljima uglavnom muškog stanovništva te bioloških razlika u očekivanoj dobi doživljenja. Starenje žena na otocima i kvaliteta života u starosti ovise o brojnim čimbenicima - (ne)sudjelovanju u migracijama njih samih ili članova njihovih obitelji, veličini zajednice u kojoj žive, stupnju izoliranosti otoka, kvaliteti postojeće infrastrukture, njihovu zdravlju, stupnju uključenosti u društveni život itd. Ujedno, starenje otočanki razlikuje se od starenja muškaraca na otocima i kopnu zbog drugačije distribuiranih radnih i društvenih uloga te znatno kasnijeg uključivanja žena u migracije i tržište rada.

Transformacija radnih i društvenih uloga žena i kontinuitet tih uloga $u$ starosti, napose radnih formalnih i neformalnih, izraženiji je u manjim otočnim zajednicama, koje su osjetlivije na promjene izazvane migracijama.

Ono što je zajedničko starim ženama bez obzira na otok koji promatramo visoka je razina aktivnosti do duboke starosti. Bez obzira na to žive li u kućanstvu same ili s bračnim partnerom, odnosno drugim članovima obitelji, radna etika stečena tijekom života u otočnom prostoru (u djetinjstvu ili mladosti za »migrantice«, a tijekom cijelog životnog ciklusa za »nemigrantice«) ostaje do duboke starosti.

Unatoč velikim društvenim promjenama, koje su utjecale na samostalnost odlučivanja žena i njihovu prisutnost u svim domenama života, nije se dogodila ravnomjerna nivelacija društvenih i ekonomskih uloga. Tako je 
primjerice pružanje neformalne skrbi, napose starijim članovima, još uvijek u velikoj mjeri rodno određeno, prije svega zbog običajâ, odgoja i ustaljenih očekivanja zajednica spram ženskih uloga i dužnosti.

U narednom razdoblju, na temelju postojećih trendova, očekuje se daljnje intenziviranje procesa starenja na hrvatskim otocima, rast broja starijih dobnih skupina (starih starih ljudi), u kojima će biti sve veći udio žena, a posljedično i sve veći broj ženskih samačkih kućanstava. To će utjecati na sve aspekte svakodnevice malih otočnih zajednica i pred društvo postaviti nove zahtjeve $\mathrm{u}$ domeni organizacije zdravstvene zaštite, formalnih i neformalnih oblika skrbi, poboljšanja ili prilagodbe komunalne infrastrukture i sl. Zbog toga se zalažemo da mjerodavne institucije (na razini države, županija, lokalnih zajednica, ali i nevladine udruge) nastave provođenje dosadašnjih, nažalost rijetkih, uspješnih projekata kojima je unaprijeđena kvaliteta života starih otočana (primjerice $u$ radu spomenuti projekt gerontodomaćica) ili pokrenu nove koji bi optimizirali mogućnosti za kvalitetan život starih osoba i dostojanstveno starenje u otočnom prostoru.

\section{LITERATURA}

Atchley, R. C. (1999). Continuity and Adaptation in Aging: Creating Positive Experiences. Baltimore: Johns Hopkins University Press.

Arber, S. i Ginn, J. (ur.) (1995). Connecting Gender and Ageing: A Sociological Approach. Buckingham: Open University Press.

Arber, S., Davidson, K. i Ginn, J. (ur.) (2003). Gender and Ageing: Changing Roles and Relationships. Maidenhead: Open University Press.

Bara, M. (2013). Povratne umirovljeničke migracije na hrvatskim otocima, Migracijske i etničke teme, 29 (2): 201-224, doi: 10.11567/met.29.2.4.

Babić, D., Lajić, I. i Podgorelec, S. (2004). Otoci dviju generacija. Zagreb: Institut za migracije i narodnosti.

Calasanti, T. M. i Zajicek, A. M. (1993). A socialist feminist approach to aging: embracing diversity, Journal of Aging Studies, 7 (2): 117-131, doi: 10.1016/0890-4065(93)90029-J.

Cummins, R. (1997). The Comprehensive Quality of Life Scale - Intellectual Disability, (ComQol - ID5): Manual. Toorak: Deakin University School of Psychology.

Cukrov, T. (2009). Mali otok pa se ljulja, sv. 1-2. Šibenik: Znanje.

Cvitanović, A. (1989). Otok Iž. Veli Iž: Mjesna zajednica Veli Iž.

Cvitanović, V. (1956). O običaju pobratimstva - posestrinstva na otoku Ižu (kod Zadra) i okolnim otocima, Radovi Instituta JAZU u Zadru, 2: 375-385.

Faričić, J. i Magaš, D. (2004). Suvremeni socio-geografski problemi malih hrvatskih otoka - primjer otoka Žirja, Geoadria, 9 (2): 125-158. 
Faričić, J., Graovac, V. i Čuka, A. (2010). Mali hrvatski otoci - radno-rezidencijalni prostor i/ili prostor odmora i rekreacije, Geoadria, 15 (1): 145-185.

Ferraro, K. F. (2001). Aging and Role Transitions, u: R. H. Binstock i L. K. George (ur.). Handbook of Aging and the Social Sciences. San Diego: Academic Press, 313-330.

Georg, L. K. i Bearon, L. B. (1980). Quality of Life in Older Pearsons - Meaning and Measurement. New York: Human Science Press.

Graovac, V. (2004). Islands on the Verge of Extinction - the Example of Zadar Islands, Croatia, Geoadria, 9 (2): 183-210.

Hareven, T. K. (2001). Historical Perspectives on Aging and Family Relations, u: R. H. Binstock i L. K. George (ur.). Handbook of Aging and the Social Sciences. San Diego: Academic Press, 141-159.

Higo, M. i Williamson, J. B. (2009). Retirement, u: D. Carr (ur.). Encyclopedia of the Life Course and Human Development, sv. 3. Farmington Hills, MI: Gale, 328-336.

Holst, N. i Plange Welleius, S. (2006/2007). What One Does, One Becomes - Gender Roles on Bellona Islands. Roskilde University, International Development Studies \& Geography. http://rudar.ruc.dk/bitstream/1800/3006/1/F\%C3\%A6rdigt\%20speciale_280607_t\%20 bibliotek.pdf (18. 08. 2014.).

Hooyman, N. R. (2002). Feminist Theory, u: D. J. Ekerdt (ur.). Encyclopedia of Aging, sv. 2. New Yourk: Macmillan Reference USA, 488-491.

Hughes, B. (1990). Quality of Life, u: S. M. Peace (ur.). Reserching Social Gerontology Concepts, Methods and Issues. London: Sage Publications, 46-58.

Jakus, K. (2002). Otok posljednjeg daha, Feral Tribune, 5. 1. 2002., 37.

Kalogjera, A. (1959). Stanovništvo i gospodarstvo otoka Prvića, Geografski glasnik, 21 (1): 69-90.

Klempić, S. i Podgorelec, S. (2002). Migracije i starenje - pet iških priča, Migracijske teme, 18 (4): 319-338.

Kranjac, A. (1981). Zlarinske narodne pjesme, poslovice i uzrečice, Narodna umjetnost, 18: 11-25.

Lajić, I. (1992). Stanovništvo dalmatinskih otoka - povijesne i suvremene značajke depopulacije. Zagreb: Institut za migracije i narodnosti Sveučilišta u Zagrebu - Consilium.

Lajić, I. i Nejašmić, I. (1994). Metodološke osobitosti demografskog istraživanja hrvatskog otočja, Društvena istraživanja, 3 (4-5): 381-396.

Lajić, I. (1997). Suvremena demografska problematika jadranskih otoka, u: N. Starc, M. Kaštelan-Macan i S. Ćurlin (ur.). Nacionalni program razvitka otoka. Zagreb: Ministarstvo obnove i razvitka, 13-32.

Lajić, I. i Mišetić, R. (2013). Demografske promjene na hrvatskim otocima na početku 21. stoljeća, Migracijske i etničke teme, 29 (2), 169-199, doi: 10.11567/met.29.2.3.

Lulić Štorić, J. (2008). Tradicijska kultura otoka Rave i njezina suvremena primjena, u: J. Faričić (ur.). Otok Rava. Zadar: Sveučilište u Zadru, 427-438.

Lulić Štorić, J. (2010). Tradicijska nošnja otoka Ista kao pokazatelj odnosa između muškarca i žene, u: J. Faričić (ur.). Otoci Ist i Škarda. Zadar: Sveučilište u Zadru [etc.], 809-816.

Medarić, J. (1957). Kretanje stanovništva i naselja, u: M. Marković (ur.). Otok Susak: zemlja, voda, ljudi, gospodarstvo, društveni razvitak, govor, nošnja, građevine, pjesma $i$ zdravlje. Zagreb: JAZU, 139-148. 
Minđek, D. (1997). Položaj žena u ruralnom Meksiku: srodstvo i odnosi spolova u Tehuitzingu, Etnološka tribina, 27 (20): 49-68.

Minkler, M. i Fadem, P. (2002). "Successful aging": a disability perspective, Journal of Disability Policy Studies, 12 (4): 229-235, doi: 10.1177/104420730201200402.

Moreno, L. (2002). Mediterranean Welfare and 'Superwomen'. Madrid: Unidad de Políticas Comparadas, http://digital.csic.es/bitstream/10261/1496/1/dt-0202.pdf (07. 06. 2012.).

Muraj, A. (1981). Obrisi svakodnevnog života zlarinskih težaka, Narodna umjetnost, 18 (1): 257-318.

Muraj, A. (1999). Samostalnost i/ili podređenost: ambivalencija društvenog položaja žena na Zlarinu, Etnološka tribina, 29 (22): 219-229.

Nejašmić, I. (1991). Depopulacija istočnojadranskih otoka i izumiranje kao moguća demografska perspektiva, Migracijske teme, 7 (1): 77-99.

Nejašmić, I. (2013). Demografsko starenje na hrvatskim otocima, Migracijske i etničke teme, 29 (2): 141-168, doi: 10.11567/met.29.2.2.

Perlmutter, M. i Hall, E. (1992). Adult Development and Aging. New York: John Wiley \& Sons, Inc.

Phillips, J., Ajrouch, K. i Hillcoat-Nallétamby, S. (2010). Key Concepts in Social Gerontology. London: SAGE Publications.

Podgorelec, S. (2008). Ostarjeti na otoku: kvaliteta života starijeg stanovništva hrvatskih otoka. Zagreb: Institut za migracije i narodnosti.

Podgorelec, S. i Klempić Bogadi, S. (2013). Gradovi potopili škoje - promjene u malim otočnim zajednicama. Zagreb: Institut za migracije i narodnosti, doi: 10.11567/2013.01.

Powell, J. L. (2006). Social Theory and Aging. Lanham, Maryland: Rowman \& Littlefield.

Roberts, B. (2002). Biographical Research. Buckingham - Philadelphia: Open University Press.Rowe, J. W. i Kahn, R. L. (1997). Successful aging, The Gerontologist, 37 (4): 433-440, doi: 10.1093/geront/37.4.433.

Schaie, W. K. i Willis, S. L. (2001). Psihologija odrasle dobi i starenja. Jastrebarsko: Naklada Slap.

Street, D. A. (2007). Sociological Approaches to Understanding Age and Aging, u: J. A. Blackburn i C. N. Dulmus (ur.). Handbook of Gerontology: Evidence-Based Approaches to Theory, Practice, and Policy. Hoboken: John Wiley \& Sons, 143-168.

Troisi, J. (2013). Ageing in Place in the Maltese Islands, u: J. Troisi i H. J. Kondratowitz (ur.). Ageing in the Mediterranean. Bristol: Policy Press, University of Bristol, 273-294.

Šimek-Škoda, K. (1951). Stanovništvo Zlarina (prilog poznavanju problema depopulacije naših otoka), Geografski glasnik, 13: 125-129.

Šućur, Z. (2011). Siromaštvo i dohodovne nejednakosti u Hrvatskoj: 2001.-2009., Revija za socijalnu politiku, 18 (2): 245-256, doi: 10.3935/rsp.v18i2.1030.

Vince-Pallua, J. (1991). Da prostite, to mi je žena! Prilog poznavanju položaja žene u drugoj polovici 18. i prvoj polovici 19. stoljeća u Dalmaciji i njezinu zaleđu, Studia ethnologica Croatica, 2 (1): 77-96.

\section{IZVORI}

Popis stanovništva, kućanstava i stanova 2011., Stanovništvo prema starosti i spolu, Državni zavod za statistiku, Zagreb, http://www.dzs.hr. 


\title{
Female Experience of Migration and Ageing - the Perspective from the Islands
}

\author{
Sonja Pogorelec, Mario Bara
}

\begin{abstract}
SUMMARY
This paper is result of research on the specificities of migration and their influence on the aging of women in particular island surroundings as well as on the causes and social consequences of these processes. It also discusses certain domains of the quality of life valued by the elderly. In addition to providing a theoretical overview, the authors present data collected by methods of secondary data analysis, and observation and semi-structured interviews in an effort to provide insight into aging on the Croatian islands from a gender standpoint. The qualitative data used were collected during several researches carried out from 2003 to 2013 within the project entitled "The influence of migrations on the regional development of Croatia". The analysis focuses mainly on the experience of elderly women who live in small island communities, defined on the basis of similar economic, social and psychological parameters regardless of the island size. The data presented in this paper indicate that the aging of women on the islands and the quality of their life in later years are dependent on a number of factors - personal or family member (non)involvement in migration, size of the community in which they live, degree of island isolation, quality of existing infrastructure, personal health, degree of participation in social life etc. Additionally, notwithstanding their individual specific life cycle or the island on which they reside, a high level of activity into very old age is a common denominator for elderly island women. In conclusion, due to current demographic trends, the authors expect the continuation of the process of population aging on the Croatian islands, increase in the number of predominantly female single households and continuation of equality in the division of roles between island males and females outside the home, with concurrent maintaining of "female roles" in the home and in caring for the elderly (professionally or volunteer), which will strengthen some quality of life related issues for the inhabitants of small island communities.
\end{abstract}

KEY WORDS: women, migration, ageing, islands, island community 